\title{
Application of Multimodality to Teaching Reading
}

\author{
Xiaoli Bao ${ }^{1}$ \\ ${ }^{1}$ School of Foreign Language, Inner Mongolia University for Nationalities, Tongliao, Inner Mongolia, China \\ Correspondence: Xiaoli Bao, School of Foreign Language, Inner Mongolia University for Nationalities, \\ Tongliao, Inner Mongolia, China. E-mail: nmbaoxiaoli@163.com
}

Received: June 14, 2017 Accepted: July 10, 2017 Online Published: August 30, 2017

doi:10.5539/ells.v7n3p78 URL: http://doi.org/10.5539/ells.v7n3p78

\begin{abstract}
To improve students' reading ability is one of the fundamental requirements for English teaching for English majors. However, some English majors are not interested in reading English and lack motivation to learn it. Even teachers may lose enthusiasm to teach them English. As a result, teaching English reading is inefficient.

Application of multimodality in teaching English has attracted many researchers' attention; the author applies multimodality to teaching English reading and attempts to answer the following question: Is the application of multimodality to teaching English reading effective?

An experiment is carried out in two parallel classes for a whole term. In the experimental class, multimodality is applied in teaching reading and teaching procedures are all designed according to the theory of elements of designing multimodality while in the control class, ordinary multimedia teaching is applied. The data of pre-test, reading quizzes, a post-test are analyzed by SPSS 16.0. The research finds out that on the one hand, the application of multimodality in teaching reading is indeed effective. On the other hand, multimodal teaching is more popular among English majors for it can help activate classroom atmosphere, inspire students' motivation to read after class and build up their confidence in learn English, especially English reading. The author also provides the suggestions for English teaching based on the research findings.
\end{abstract}

Keywords: multimodality, English majors, reading ability, English reading teaching

\section{Introduction}

Most teachers still apply traditional teaching model which is teacher-centered. It can hardly arouse students' interest and the learning efficiency in reading class is low. Therefore, there is great need to improve the teaching method in reading class.

Enabling students to learn basic language knowledge and practicing basic language skills are the objectives of teaching students English. Students' overall ability to use English should be improved according to curriculum requirements and reading ability is the basis and should be emphasized. However, teaching reading in college is far from satisfaction, most teacher now still apply the traditional teaching methods in reading class which makes students feel bored.

Studies on multimodality have attracted a lot attention since 1990. Scholars try to apply multimodality to language teaching and provide many valuable suggestions. However, in China, the application of multimodality in education is still in the initial stage. Most researches are related to the introduction and construction of the theoretical basis of multimodality, but few are empirical studies. Therefore, researchers in China should conduct more teaching experiments to fill in the gap.

This study aims to find out whether application of multimodality to teaching reading is popular among English majors and how it affects students' learning reading. Through this study, a new kind of teaching model may be proved to be successful in teaching English reading and the author also hopes to provide some suggestions for English reading teaching.

\section{Theory}

\subsection{Studies on Teaching Reading}

\subsubsection{Definition of Reading}

Different scholars define reading in different ways. Many scholars believe that reading is a matter of transferring 
meaning from mind to mind and of passing messages from writer to readers. In order to make sure this kind of transfer, the writer and the text should all contribute positively to the reading process. The reading passages or text materials are the carrier of information and writers transmit information to the outside world through them. Meanwhile, readers extract information from the reading passages and process the information.

\subsubsection{Main Models of Reading}

Researchers have developed different kinds of models of reading, among which bottom-up, top-down and interactive are the three most important ones. 1) Bottom-up model. Gough depicts the reading process as an additive process in which the reader puts symbols together into phrases, phrases into sentences and sentences into overall meaning (quoted in Kavanagh \& Mattingly, 1974). That is to say, readers comprehend the text letter by letter, word by word and sentence by sentence. Therefore, this model requires a sophisticated knowledge of the language during the reading process. This model reflects the traditional view that reading teaching should emphasize vocabulary and grammar. Some scholars believe this model can effectively help readers understand the meaning of the text, but other scholars believe readers using this model cannot catch the general idea and are not active in the reading process. The model lays little emphasis on the influence of the reader's prior knowledge, contextual information and other processing methods. 2) Top-down model. Goodman believes the entire reading process is "a psycholinguistic guessing game" (quoted in Gollasch 1982, pp. 33-34). It is argued that the goal of reading is constructing meaning in response to text and that reading requires interactive use of graph-phonic, syntactic and semantic cues to construct meaning. Readers are required to take advantage of the intelligence and experience to predict and comprehend the text in order to get the general idea. These models play an important role in the reading process while readers are confronted with very difficult reading passages with a lot of new words and complicated structures. But such top-down processing can easily lead to the neglect of the language learning, hindering students' development of basic language competence in the reading process. 3) Interactive modal. Rumelhart believes that interactive reading model is the most effective process of reading in which the bottom-up model and the top-down model work interactively (quoted in Singer \& Riddell 1985), which mean readers can use a top-down method to predict the probable meaning and then move on to the bottom-up method to check whether it is really the author's intention.

\subsubsection{Main Methods of Teaching Reading}

There are three main methods of teaching reading: 1) Grammar-translation method. Grammar-translation method regards langue learning as memorizing rules and facts to understand and manipulate the morphology and syntax of the target language. 2) Communicative method. Communicative method is a way of teaching language in terms of its use for communication and considers it important to be able to use the target language to express meaning appropriately in a context. 3)Task-based method. Task-based method is the development of communicative method and it asks students to do meaningful tasks by using the target language. Communicative method emphasizes "learning while doing".

\subsection{Studies on Multimodality}

\subsubsection{Definition of Multimodality}

Scholars define multimodality in different ways. Van Leeuwen (2005) notes multimodality means the combination of different semiotic modes. Jewitt (2006) defined multimodality as two means of representation and communication, such as still image, gesture, posture, speech, music, writing, or new configurations of the elements of these. Therefore, it can be concluded that multimodality is the mixture of several semiotic modes, which is nearly always present in communication. The combination of these modes within a socio-cultural domain causes a semiotic activity, especially the use of modes of meaning other than linguistic, including visual meanings (images, page layouts, screen formats); audio meanings(music, sound effects); gestural meanings (body language, sensuality);spatial meanings(the meanings of environmental spaces, architectural spaces)etc. In language teaching and learning, the selection of different multimodalities will bring out different effect in classroom and teachers should take it into consideration.

\subsubsection{Research on Multimodality in Teaching Home and Abroad}

Gunther Kress, Carey Jewitt and Jon Osborne Charalampos Tsatsarelis first published Multimodal teaching and Learning: The Rhetoric of the Science Classroom In 2001. Gunther Kress and Theo Van Leeuwen published Multimodal Discourse: The Modes and Media of Contemporary Communication In 2001. In the book, the concept of multimodality and the differences of modes and media are illustrated through some examples. Language, images and sound can be used in the discourse as multimodality. Material resources are used as media for production. Design is fully explained in this book and is supposed to exist between content and expression. 
Terry Royce made study of multimodality through the book Multimodality in the TESOL Classroom: Exploring Visual Verbal Synergy, in which the author reaches the conclusion that the interrelatedness of semiotic resources has the potential to conceptualize pedagogical approaches. To some degree, it provides a foundation for research on how learners interact with multimodal material in the classroom.

It was not until the early 2005 that multimodality studies began in China. Zhang (2009, pp. 15-20) pointed out multimodality studies in China are still in its infant stage. Hu \& Dong (2006, pp. 3-12) analyzed 23 PPT presentation texts and concluded that the value of PPT presentation lies in its use of images and sound effects that also construe the thematic meaning. Zhu (2007, pp. 82-86) tries to discuss four issues related to multimodal discourse analysis.1) where multimodal discourse comes from; 2) how multimodal discourse is defined; 3) what is the nature and theoretical basis of multimodal discourse analysis; 4) What is the content, methodology and significance of multimodal discourse analysis. Since 2010scholars have applied multimodality to different types of teaching. Cao (2014) applies multimodality to College English teaching in visual-audio-oral course and concludes that the application is effective in improving students' oral and listening ability. Students are interested in the multimodality and become more willing to practice after class. Song (2013) and Liu (2014) both carry out experiments to verify the effectiveness of the application of multimodality to teaching intensive reading.

\subsubsection{Elements of Designing Multimodality}

In 1996, the New London Group also offered a more complete system of modality elements. The design elements are classified into five categories, including visual design elements, audio design elements, linguistic design elements, gestural design elements and spatial design elements. In each design category, there are also more sophisticated small elements for designers to choose. Linguistic design elements include vocabulary design, the design of collocation, lexicalization, word meaning, the designs of information structures and coherence relations, modality and transitivity design, and the design of features of intonation, stress, rhythm, accent, etc... Visual design elements can be used to draw the viewers' attention. They are essential tools to present detailed information. This category involves elements, such as images, color, fonts, bar graphs, texts, icons symbols, and their geographical location, etc. Under most circumstances, designers usually like using images as visual elements. Audio elements are easy to identify. For example, background music and listening materials all belong to this category. In addition, some other elements of this category cannot be ignored, such as volume, pitch, pacing, and rhythmic. Audio elements are often used in order to make the reading process more colorful. Gestural elements consist of behavior, gestures, feelings, affect, kinesics and proxemics. These design elements draw on knowledge about modality, recurring symbolism, inherent values in body, language and gestures, and use of the body (posture, facial expressions, lip synchronizing, gaze etc.). Spatial design elements involve the design of classroom setting and the settings of the multimodal products. This kind of elements may not be noticed all the time and in this thesis, it is not emphasized a lot. From all the analysis of the elements above, the materials for multimodality design in the classroom are well-prepared.

\section{Methods}

\subsection{Research Questions}

The author tries to answer the following research question: Is the application of multimodality to teaching college English majors English reading effective?

\subsection{Subjects}

All the students taking part in the experiment are English majors from Inner Mongolia University for Nationalities. The two parallel classes are selected according to scores of reading part in the final exam before the experiment in order to make sure the subjects have similar reading ability. In this experiment, one class is selected as the experimental class and the other is the control class and there are 55 students in each of the two classes. The same English teacher (the author) applies multimodal reading teaching in the experimental class and ordinary multimedia reading teaching in the control class.

\subsection{Instruments}

There is an instrument, reading test papers. There are pre-test, reading quizzes and post-test in this research. Pre-test papers are arranged before the experiment. The quiz papers are arranged during the whole term in the process of the experiment. The post-test are arranged after the experiment. These papers are designed to test students' reading ability and with the help of these test papers, the author can collect the data and answer the research questions. 


\subsection{Research Design}

One hundred and ten students in two classes take part in the experiment, which lasts for about 16 weeks. The reading teaching usually happens during the intensive reading course. The entire experiment includes threes important stages: the pre-test, the experiment and quizzes and the post-test.

In pre-test stage, the scores of reading part in the final exam before the experiment are collected and analyzed to make sure that the reading ability of the students in the two classes is at the same level. There are four reading passages in the final exam with 15 multiple choices and each question accounts for 2 points. Reading passages' styles are different including a passage related to science and technology, an interesting story, travel guidance and a biography.

In the while-test stage, two different kinds of teaching models are used respectively in the experimental class and the control class. The quizzes for each class are five times. The quizzes are conducted every three weeks. The teaching materials, the teaching periods, the teaching pace are ensured to be the same for the two classes. New Horizon English Book1 was used as the text book. There are two passages in each unit, which takes two weeks to finish. In additions to that, all the five quiz papers are the same, each of which included two passages with 16 multiple choices and each question accounts for 2 points. The scores of the quizzes are collected and the mean scores are used to test the effectiveness of the reading teaching. The changing trend of the scores is also observed to see if the application of multimodality can improve students' reading ability gradually.

In the post-test stage, all the students in the two classes take the final exam and scores of reading part are collected as the post-test data. There are four passages of different styles and still totally 15 multiple choices for students to finish and each question accounts for 2 points. Then the reading scores of three stages are collected as the main data for analysis to answer the research question.

\section{Results and Discussion}

\subsection{Comparison and Analysis of Reading Scores in the Pre-test}

The data of the pre-test scores was analyzed by the software SPSS 16.0. The Independent Sample Test was carried out and the following tables are the results.

Table 1. Group statistics

\begin{tabular}{lllll}
\hline group & $\mathrm{N}$ & Mean & Std. Deviation & Std. Error Mean \\
\hline Pro-test 1 & 55 & 22.509 & 5.1204 & .6 .928 \\
2 & 55 & 21.164 & 5.2032 & .7 .030 \\
\hline
\end{tabular}

Table 2. Independent samples test for Pre-test

\begin{tabular}{|c|c|c|c|c|c|c|c|c|c|}
\hline & \multicolumn{2}{|c|}{$\begin{array}{l}\text { Levene's Test for } \\
\text { Equality of } \\
\text { Variances }\end{array}$} & \multicolumn{7}{|c|}{ T-test for Equality of Means } \\
\hline & \multirow[t]{2}{*}{$\mathrm{F}$} & \multirow[t]{2}{*}{ Sig. } & \multirow[t]{2}{*}{$\mathrm{t}$} & \multirow[t]{2}{*}{ df } & \multirow[t]{2}{*}{$\begin{array}{l}\text { Sig. } \\
\text { (2-tailed) }\end{array}$} & \multirow[t]{2}{*}{$\begin{array}{l}\text { Mean } \\
\text { Difference }\end{array}$} & \multirow[t]{2}{*}{$\begin{array}{l}\text { Std. Error } \\
\text { Difference }\end{array}$} & \multicolumn{2}{|c|}{$\begin{array}{l}95 \% \text { Condifence Interval } \\
\text { of the Difference }\end{array}$} \\
\hline & & & & & & & & Lower & upper \\
\hline $\begin{array}{l}\text { Pre-test Equal } \\
\text { variances assumed }\end{array}$ & .0 .51 & .820 & 1.355 & 107 & .165 & 1.3355 & .9757 & -.6084 & 3.2993 \\
\hline $\begin{array}{l}\text { Equal variances not } \\
\text { assumed }\end{array}$ & & & 1.355 & 106.97 & .1665 & 1.3355 & .9757 & -.6084 & 3.2993 \\
\hline
\end{tabular}

It can be seen from the table that the mean score of the experimental class is 22.509 while that the score of the control group is 21.164 , which show the difference between the two classes is very small. If the Sig. (2-tailed) value is lower than 0.05 , it can be concluded there is significant difference between the two classes. In this test, the Sig. (2-tailed) value is $0.165<0.05$; it means there is no difference between the scores of the two classes. They have the same reading level.

\subsection{Comparison and Analysis of Scores of Reading Quizzes}

The following table shows the mean of each quiz during the term and the last one is the mean of all five quizzes.

The full score of each quiz is sixteen. 
Table 3. Mean scores of reading quizzes

\begin{tabular}{lllllll}
\hline \multicolumn{1}{c}{ No. } & 1 & 2 & 3 & 4 & 5 & mean \\
Group & & & & & & \\
\hline experimental & 9.65 & 9.76 & 10.3 & 14.59 & 12.51 & 11.36 \\
control & 9.21 & 8.00 & 8.36 & 10.37 & 9.10 & 9.03 \\
\hline
\end{tabular}

From the table we can see that students' scores in the experimental class are higher than the control class in every quiz. We can also see that the gap between the two classes is becoming greater. The later the test is, the bigger the difference is. At the beginning, the scores are nearly the same and the difference in the mean is only less than one point, but as time passes by, the gap between the two classes' increases to higher than three points. Furthermore, from the perspective of the changing tendency, it can be noticed that the students in the experimental class is making greater progress than the control class in the process.

Independent samples test for quizzes reconfirm the conclusion. The following is the result of the Independent Sample Test.

Table 4. Independent sample test for quizzes

\begin{tabular}{llllllllll}
\hline & $\begin{array}{l}\text { Levene's Test for } \\
\text { Equality of } \\
\text { Variance }\end{array}$ & & \multicolumn{2}{l}{ T-test for Equality of Means } \\
& F & Sig. & $\mathrm{t}$ & $\mathrm{df}$ & Sig (2-tailed) & $\begin{array}{l}\text { Mean } \\
\text { Difference }\end{array}$ & $\begin{array}{l}\text { Std.Error } \\
\text { Difference }\end{array}$ & $\begin{array}{l}95 \% \text { Confidence Interval } \\
\text { of the Difference } \\
\text { lower }\end{array}$ \\
\hline $\begin{array}{l}\text { Reading mean Equal } \\
\text { variances assumed }\end{array}$ & .013 & .906 & 6.866 & 108 & .000 & 2.3482 & .3420 & 3.0262 & 1.6510 \\
$\begin{array}{l}\text { Equal variances not } \\
\text { assumed }\end{array}$ & & & 6.866 & 107.489 & .000 & 2.3482 & .3420 & 3.0262 & 1.6509 \\
\hline
\end{tabular}

We know If the Sig. (2-tailed) Value is lower than 0.05, it can be concluded that there is significant difference between the two classes, but if the Sig. (2-tailed) Value is equal to or higher than 0.05 , the conclusion will be totally opposite. In this test the Sig. (2-tailed) Value is $0.000<0.05$, which means there is significant difference between the scores of the two classes. The conclusion above has been reconfirmed. That means, during this term, the application of multimodality helps students improve the reading ability a lot and with time passing by, the effect is becoming greater.

\subsection{Comparison and Analysis of Reading Scores in the Post-test}

In the post-test stage, all the students in the two classes take the final exam and scores of reading part are collected as the post-test data. The SPSS 16.0 carries out the Independent Sample Test to see if there is significant difference between the two classes. The following is the result of the test.

Table 5. Mean scores of reading quizzes

\begin{tabular}{llllll}
\hline & group & $\mathrm{N}$ & Mean & Std. Deviation & Std. Error Mean \\
\hline Post-test & 1 & 55 & 26.801 & 5.2401 & .7068 \\
& 2 & 55 & 22.461 & 5.2105 & .7032 \\
\hline
\end{tabular}

Table 6. Independent samples test

\begin{tabular}{|c|c|c|c|c|c|c|c|c|c|}
\hline & \multicolumn{9}{|c|}{ Levene's Test for } \\
\hline & $\mathrm{F}$ & Sig. & $\mathrm{t}$ & $\mathrm{df}$ & $\begin{array}{l}\text { Sig } \\
\text { (2-tailed) }\end{array}$ & $\begin{array}{l}\text { Mean } \\
\text { Difference }\end{array}$ & $\begin{array}{l}\text { Std. Error } \\
\text { Difference }\end{array}$ & $\begin{array}{l}95 \% \mathrm{Cc} \\
\text { of the } \mathrm{D}\end{array}$ & ce Interval \\
\hline & & & & & & & & lower & upper \\
\hline $\begin{array}{l}\text { Reading mean Equal } \\
\text { variances assumed }\end{array}$ & .023 & .854 & 4.528 & 108 & .000 & 4.432 & .9946 & 2.5443 & 6.4816 \\
\hline $\begin{array}{l}\text { Equal variances not } \\
\text { assumed }\end{array}$ & & & 4.528 & 107.989 & .000 & 4.432 & .9946 & 2.5443 & 6.4816 \\
\hline
\end{tabular}


From the first table, we can see the mean score of the experimental class is 26.801 while that of the control class is only 22.461. Obviously, after the multimodal teaching for the whole term, the experimental class has got a much higher than the control class. The difference in the mean prove the conclusion to some degree, but the data of the Independent Sample Test must be accurate. In this test the Sig. (2-tailed) Value is $0.000<0.05$, which means there is indeed significant difference between the scores of the two classes. From this analysis, the result should be more convincing.

The reading ability of the two classes are nearly the same at the beginning, but after a whole term's learning, students have made great progress in reading, which indicates the application of multimodality to teaching reading is really effective for English majors.

\section{Conclusions}

It can be clearly concluded through the teaching experiment that the application of multimodality surely affects English majors' reading ability. The application of multimodality to teaching reading is effective.

Many students have difficulties in learning English reading, due to their low level of English. But they have advantages in perceiving different kinds of modalities which can be made full use of. According to the data and analysis in the previous chapter, students in the experimental class have improved their reading ability much more and meanwhile, students have made greater and greater progress as time passes by. That is to say, the application of multimodality can indeed help improve English majors' reading ability and it is really an effective way for teachers to teach English reading. Application of multimodality not only makes the atmosphere in the class more relaxing and interesting but also motivates students to do more reading after class. Furthermore, it can make students more confident in learning English especially English reading.

There are some limitations in this research. The subjects are all from one university who cannot represent all the students majoring in English. The experimental time is limited, and if it lasts for longer periods, the data can be more accurate and the result will be more convincing. The author hopes more language teaching researches related to application of multimodality can be carried out and then it will produce more bountiful fruits, thus helping improve English teaching in the future.

\section{Acknowledgments}

This article is the final result of educational and pedagogical project of Inner Mongolia University for Nationalities. The project is supported by center for faculty development. Ratification number is YB2016026.

\section{References}

Cao, L. (2014). An Experimental Study on College English Teaching in Visual-audio-oral Course Based on Multimodality. Jilin University.

Gollasch, F. V. (1982). Language and Literacy: the Selected Writings of Kenneth S. Goodman. London: Routledge and Kegan Paul.

Jewitt, C. (2006). Technology, Literacy, and Learning: A Multimodal Approach. New York: Routledge.

Kavanagh, J. F., \& Mattingly, I. G. (1974). Language by Ear and by Eye. Cambridge: MIT Press.

Kress, G. (2003). Literacy in the New Media Age. London: Routledge. https://doi.org/10.4324/9780203164754

Kress, G. et al. (2001). Multimodal Teaching and Learning: The Rhetoric of the Science Classroom. London and New York: Continuum.

Kress, G., \& Van Leeuwen, T. (2001). Multimodal Discourse: The Modes and Media of Contemporary Communication. London: Arnold.

Song, Q. (2013). Application of Multimodality to Teaching of College English Intensive Reading. Changchun University of Science and Technology.

Van Leeuwen, T. (2005). Introducing Social Semiotics. London and New York: Routledge.

Zhang, D. (2009). The Application of Multimodal Discourse Theory and Multimedia Technology in Foreign Language Teaching. Foreign Language Teaching, 30(4), 15-20.

Zhu, Y. (2007). The Theoretical Basis and Research Methods of Multimodal Discourse Analysis. Foreign Languages Research, (5). 


\section{Copyrights}

Copyright for this article is retained by the author, with first publication rights granted to the journal.

This is an open-access article distributed under the terms and conditions of the Creative Commons Attribution license (http://creativecommons.org/licenses/by/4.0/). 